\title{
Assessing Variation in US Soybean Seed Composition (Protein and Oil)
}

\section{OPEN ACCESS}

Edited by:

Luis A. N. Aguirrezabal, National University of Mar del Plata, Argentina

Reviewed by: Joaquín J. Salas, Instituto de la Grasa (IG), Spain Hardy Rolletschek, Leibniz-Institut für Pflanzengenetik und Kulturpflanzenforschung (IPK),

Germany

*Correspondence: Yared Assefa yareda@ksu.edu Ignacio A. Ciampitti ciampitti@ksu.edu

Specialty section: This article was submitted to Crop and Product Physiology, a section of the journal Frontiers in Plant Science

Received: 18 December 2018 Accepted: 25 February 2019 Published: 11 March 2019

Citation:

Assefa Y, Purcell LC, Salmeron M, Naeve S, Casteel SN, Kovács $P$, Archontoulis S, Licht M, Below F, Kandel H, Lindsey LE, Gaska J, Conley S, Shapiro C, Orlowski JM, Golden BR, Kaur G, Singh M,

Thelen K, Laurenz R, Davidson D and Ciampitti IA (2019) Assessing Variation in US Soybean Seed Composition (Protein and Oil).

Front. Plant Sci. 10:298. doi: 10.3389/fp/s.2019.00298
Yared Assefa ${ }^{1 *}$, Larry C. Purcell ${ }^{2}$, Montse Salmeron ${ }^{3}$, Seth Naeve ${ }^{4}$, Shaun N. Casteel ${ }^{5}$, Péter Kovács ${ }^{6}$, Sotirios Archontoulis ${ }^{7}$, Mark Licht ${ }^{7}$, Fred Below ${ }^{8}$, Herman Kandel ${ }^{9}$, Laura E. Lindsey ${ }^{10}$, John Gaska ${ }^{11}$, Shawn Conley ${ }^{11}$, Charles Shapiro ${ }^{12}$, John M. Orlowski ${ }^{13}$, Bobby R. Golden ${ }^{13}$, Gurpreet Kaur ${ }^{13}$, Maninderpal Singh ${ }^{14}$, Kurt Thelen ${ }^{14}$, Randall Laurenz ${ }^{14}$, Dan Davidson ${ }^{15}$ and Ignacio A. Ciampitti ${ }^{1 *}$

${ }^{1}$ Department of Agronomy, Kansas State University, Manhattan, KS, United States, ${ }^{2}$ Department of Crop, Soil, and Environmental Sciences, University of Arkansas, Fayetteville, AR, United States, ${ }^{3}$ Department of Plant and Soil Sciences, University of Kentucky, Lexington, KY, United States, ${ }^{4}$ Department of Agronomy and Plant Genetics, University of Minnesota, Saint Paul, MN, United States, ${ }^{5}$ Department of Agronomy, Purdue University, West Lafayette, IN, United States,

${ }^{6}$ Department of Agronomy, Horticulture \& Plant Science, South Dakota State University, Brookings, SD, United States, ${ }^{7}$ Department of Agronomy, lowa State University, Ames, IA, United States, ${ }^{8}$ Department of Crop Sciences, University of Illinois at Urbana-Champaign, Urbana, IL, United States, ${ }^{9}$ Department of Plant Sciences, North Dakota State University, Fargo, ND, United States, ${ }^{10}$ Department of Horticulture and Crop Science, The Ohio State University, Columbus, OH, United States, ${ }^{11}$ Department of Agronomy, University of Wisconsin-Madison, Madison, WI, United States, ${ }^{12}$ Department of Agronomy and Horticulture, University of Nebraska System, Lincoln, NE, United States, ${ }^{13}$ Delta Research and Extension Center, Mississippi State University, Stoneville, MS, United States, ${ }^{14}$ Department of Plant, Soil and Microbial Sciences, Michigan State University, Allegan, MI, United States, ${ }^{15}$ Illinois Soybean Association, Bloomington, IL, United States

Soybean [Glycine max (L.) Merr.] seed composition and yield are a function of genetics $(G)$, environment (E), and management (M) practices, but contribution of each factor to seed composition and yield are not well understood. The goal of this synthesis-analysis was to identify the main effects of $G, E$, and $M$ factors on seed composition (protein and oil concentration) and yield. The entire dataset (13,574 data points) consisted of 21 studies conducted across the United States (US) between 2002 and 2017 with varying treatments and all reporting seed yield and composition. Environment (E), defined as site-year, was the dominant factor accounting for more than $70 \%$ of the variation for both seed composition and yield. Of the crop management factors: (i) delayed planting date decreased oil concentration by 0.007 to $0.06 \%$ per delayed week $\left(R^{2} \sim 0.70\right)$ and a 0.01 to $0.04 \mathrm{Mg} \mathrm{ha}^{-1}$ decline in seed yield per week, mainly in northern latitudes (40-45 N); (ii) crop rotation (corn-soybean) resulted in an overall positive impact for both seed composition and yield $\left(1.60 \mathrm{Mg} \mathrm{ha}^{-1}\right.$ positive yield difference relative to continuous soybean); and (iii) other management practices such as no-till, seed treatment, foliar nutrient application, and fungicide showed mixed results. Fertilizer $\mathrm{N}$ application in lower quantities (10-50 kg N ha-1) increased both oil and protein concentration, but seed yield was improved with rates above $100 \mathrm{~kg} \mathrm{~N} \mathrm{ha}^{-1}$. At southern latitudes (30-35 N), trends of reduction in oil and increases in protein concentrations with later maturity groups (MG, from 3 to 7) was found. Continuing coordinated research is critical to advance our understanding of $\mathrm{G} \times \mathrm{E} \times \mathrm{M}$ interactions.

Keywords: crop environment, soybean management, protein yield, oil concentration, seed quality

Abbreviations: DOY, day of the year; E, environment; G, genetics; M, management; MG, maturity group. 


\section{INTRODUCTION}

Soybean seed yield and quality are functions of genotype $(G)$, $\mathrm{M}, \mathrm{E}$, and their interaction $(\mathrm{G} \times \mathrm{E} \times \mathrm{M})$, but how each individual factor affects seed yield and quality, and their level of significance is not well established (Rao et al., 2002; Assefa et al., 2018). Previous studies have reported mixed results for climatic factors, such as temperature and solar radiation on soybean growth and seed composition (Cartter and Hopper, 1942; Maestri et al., 1998: Grieshop and Fahey, 2001; Dardanelli et al., 2006; Goldflus et al., 2006). For example, a few studies reported an increase in oil without any effect on protein concentration as temperature increases (Howell and Cartter, 1958; Ren et al., 2009; Mourtzinis et al., 2017a). Kumar et al. (2006) showed a positive linear relationship between temperature and protein concentration, but a negative relationship between temperature and oil concentration. Some other studies reported quadratic relationships of oil and protein concentration with temperature (Piper and Boote, 1999; Pipolo et al., 2004).

Soybean seed composition is also affected by the application of nutrients and water depending on the availability of resources and crop yield potential. Ham et al. (1975) and Nakasathien et al. (2000) reported an increase in protein concentration and a decline in oil with increased application of nitrogen (N) fertilization, whereas Wood et al. (1993) reported lack of response from both soybean oil and protein concentration to fertilizer $\mathrm{N}$ application. In testing the different combinations of foliar nutrient fertilization on soybean in 112 field trials in Iowa, Haq and Mallarino (2005) concluded that total oil and protein production response to fertilizer followed a similar patter with yield response. However, they noted small, erratic and inconsistent changes in oil and protein concentrations. In a meta-analysis, Rotundo and Westgate (2009), concluded that providing supplemental $\mathrm{N}$ increased both protein concentration and content but slightly decreased oil concentration. The impact of irrigation on protein concentration was dependent on the soybean genotypes (Boydak et al., 2002; Bellaloui and Mengistu, 2008). A decline in protein concentration with water deficit during reproductive stages was reported by Carrera et al. (2009), whereas Kumar et al. (2006) reported an increase in protein concentration with decreased precipitation. In a metaanalysis for soybean seed composition, Rotundo and Westgate (2009) documented an overall relative positive response to water stress of protein concentration, regardless of the timing of the stress and studies (field and pot trials). The same authors found an overall negative impact of water stress on both oil concentration and content.

Besides $\mathrm{E}$ and inputs, crop $\mathrm{M}$ and $\mathrm{G}$ also affect soybean seed composition and yield. A negative impact of continuous soybean cropping on protein and oil composition relative to soybean rotation with corn (Zea mays L.) (Bellaloui et al., 2010) or its intercropping with sorghum (Sorghum bicolor L.) (Elsheikh et al., 2009) has been noted. The impact of planting date on oil and protein concentration appears mixed with a benefit for oil from early planting, whereas late planting promoting protein concentration (Robinson et al., 2009; Bellaloui et al., 2015), or a benefit to both protein and oil from early planting
(Jaureguy et al., 2013). Further analysis of impact of planting data by genotypes and possible contributing factors related to obtained results were also topics of study (Rowntree et al., 2013, 2014). The difference in the definition of early or late planting and lack of detailed weather characterization may complicate interpretation of these reports. Therefore, the objective of this manuscript was to identify the main effects of G, E, and M factors influencing seed composition (protein and oil) and their association with soybean yield through meta-analysis and synthesis of a database obtained across the United States.

\section{MATERIALS AND METHODS}

The dataset $(13,574$ data points) consisted of 21 studies from 11 states within the major soybean producing regions of the United States Impacts of different treatments on soybean seed composition (protein and oil) and yield were among the main response variables (Table 1). In addition, several studies were conducted across years at the same locations. Location of each study is presented in Figure 1. Treatments and experimental designs varied across studies. However, each of these studies have reported similar independent variables or covariates (planting and harvesting date, location, year, fertilizer rate, other $\mathrm{M}$ ) and comparable response variables (oil, protein, or yield). Analysis of the overall distribution and relationships among response variables were conducted for the entire data set but specific factor effect analysis was conducted using studies that have similar range of treatments. Soybean seed oil and protein concentrations were measured using near infrared transmittance (NIT) spectroscopy (Infratec 1241 Grain Analyzer, Foss Instruments, Eden Prairie, MN or DA 7250 NIR analyzer, Perten Instruments, Inc., Springfield, IL, United States) and seed yield measurements were adjusted to $130 \mathrm{~g} \mathrm{~kg}^{-1}$ seed moisture content. By creating a regional and large database, we have increased the power of detecting the effect of the treatments representing $\mathrm{G} \times \mathrm{E} \times \mathrm{M}$ combinations on the measured response variables.

\section{Statistical Analysis}

We used a five-step process to analyze the data. First, we determined the distribution of oil, protein, and seed yield across the US soybean database. Yield distribution was further investigated by latitude groups obtained by the UNIVARIATE procedure in SAS (SAS Institute, 2012). Then, the overall relationship between oil concentration and oil yield with seed yield, protein concentration and protein yield with seed yield, and the relationship between oil and protein concentrations were all studied using PROC REG procedure in SAS. Even though the main objective was to obtain the combined overall relationship among the response variables, analysis was also conducted by study or group of studies (for locations with multiple studies).

Second, the database was classified into 103 Es based on the site-year information. A 1-year field trial with different treatments (planting date, tillage, or other) at a given location was considered as an E. The first analysis was conducted to determine the impact of the E on protein, oil, and seed yield. These three 


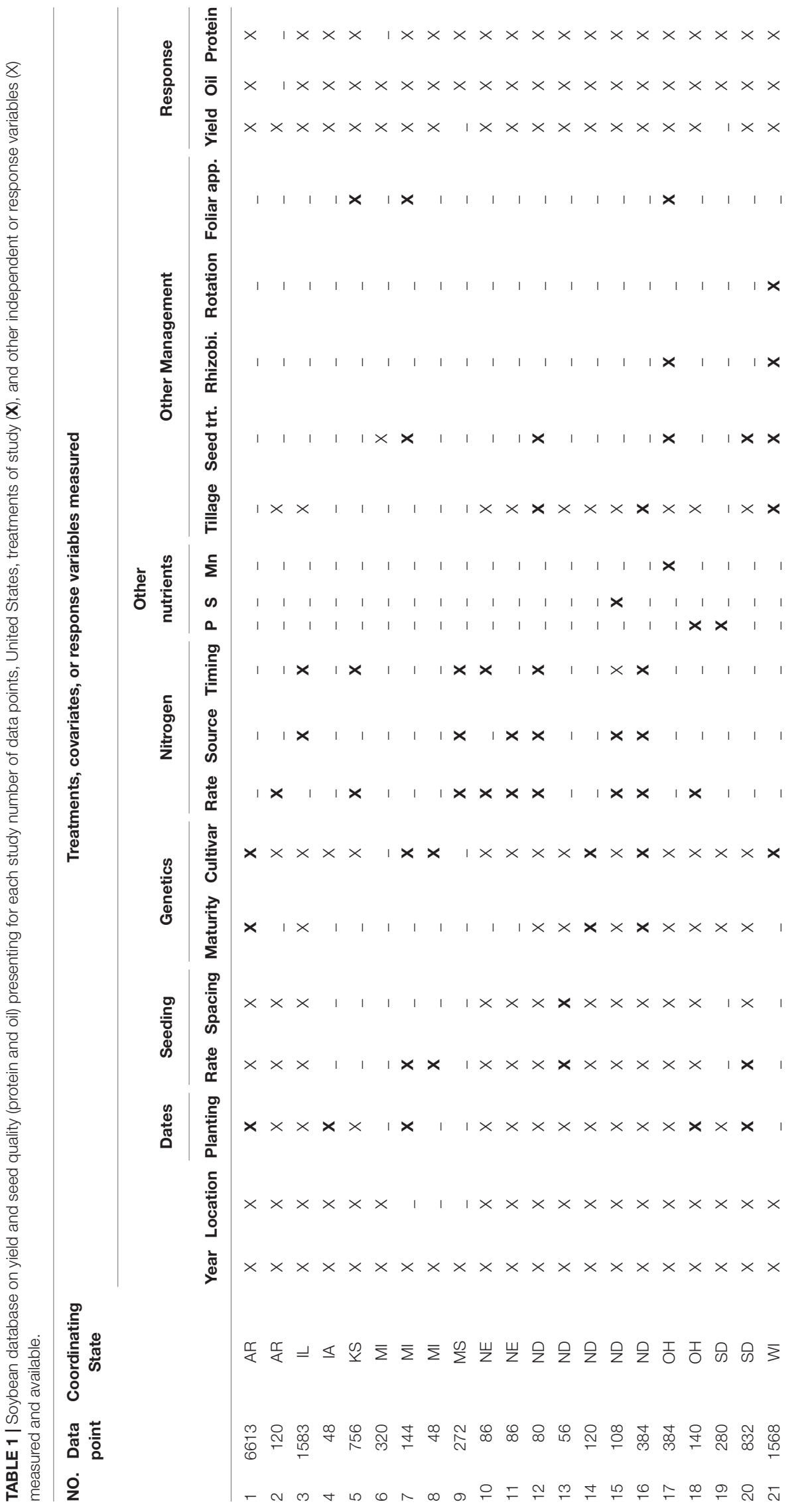




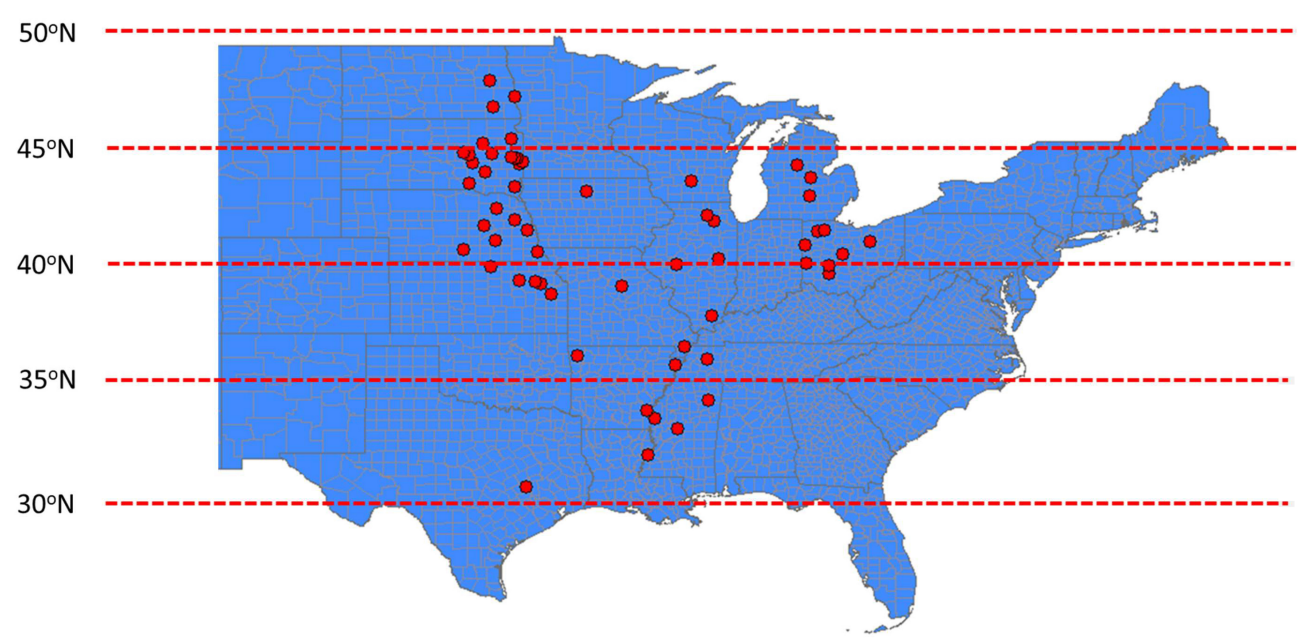

FIGURE 1 | Partial map of the United States (US) showing the locations for all field trials conducted and utilized to create the soybean seed yield and quality (protein and oil) database. Geographical locations are presented as red circles.

response variables were modeled separately against $\mathrm{E}$ as a fixed variable in the PROC GLM procedure in SAS. The result of this model fit, the $\mathrm{R}^{2}$, was used to explain the proportion of variation explained by or accounted for $\mathrm{E}$ for protein, oil, and seed yield, as response variables.

In the third step, the impact of different $M$ factors was investigated by dividing the data into two groups: (i) planting date or (ii) other $M$ factors. The impact of planting date, as continuous variable was studied by latitude groups. Planting dates were grouped by weeks from the earliest to the latest planting date for all the studies gathered in the database. Then, the PROC MEAN procedure was used to determine the minimum, mean, and maximum values of oil, protein, or seed yield for each planting week. Interpretation of data was done based on linear fitted trends to mean values of the seed composition and seed yield over planting week by latitude group. For $M$ variables such as tillage, rotation, seed treatment that have a categorical contrast of treatments (e.g., for tillage factor, conventional versus no-till), a meta-type analysis was conducted. The forest-plot of the mean differences was used to present overall effects of each $\mathrm{M}$ factor and this analysis was conducted in R using R package meta (Lewis and Clarke, 2001; R Development Core Team, 2012). These forest plots present the difference between the mean response of improved technology over the traditional (control) and the standard error attached to the mean difference.

The fourth step considered application of inputs such as $\mathrm{N}$ fertilizer effects on oil, protein, and seed yield. The amount of $\mathrm{N}$ fertilizer varied from study-to-study. Therefore, we grouped the $\mathrm{N}$ rates into five categories (control, $0 \mathrm{~kg} \mathrm{ha}^{-1}, 10-50 \mathrm{~kg}$ $\mathrm{ha}^{-1}, 50-100 \mathrm{~kg} \mathrm{ha}^{-1}, 100-150 \mathrm{~kg} \mathrm{ha}^{-1}$, and $>150 \mathrm{~kg} \mathrm{ha}^{-1}$ ) and determined the exceedance probability of seed composition and yield level at each $\mathrm{N}$ rate category using UNIVARIATE procedure of SAS. Exceedance probability here is defined as the probability of obtaining oil, protein, or yield exceeding the indicated amount for each $\mathrm{N}$ rate category.
For the fifth step, the effect of $M G$ of varieties (G) was studied by latitude groups. The minimum-, mean-, and maximum-oil, protein, or seed yield by MG of each variety by latitude was determined using the PROC MEAN procedure. Regression analysis was conducted on mean and the coefficient of determination $\left(R^{2}\right)$ is presented when the relationship was statistically significant $(P<0.05)$. Interpretation of data was done by studying the trends of the minimum, mean, or maximum values of the variables as MG changes in each latitude group. We recognize that this analysis does not account for genetic differences within MG.

\section{RESULTS AND DISCUSSION}

\section{Environment, Data Distribution, and Relationships}

Oil concentration in soybean ranged from 132 to $246 \mathrm{~g} \mathrm{~kg}^{-1}$ (Figure 2). The mean oil concentration was $195 \mathrm{~g} \mathrm{~kg}^{-1}$, and $90 \%$ of the data were within a $30 \mathrm{~g} \mathrm{~kg}^{-1}$ range, i.e., from 180 to $210 \mathrm{~g} \mathrm{~kg}^{-1}$. Protein concentration ranged from 273 to $454 \mathrm{~g}$ $\mathrm{kg}^{-1}$ (Figure 2). The mean protein concentration was $357 \mathrm{~g} \mathrm{~kg}^{-1}$, and $90 \%$ of the data were within a $60 \mathrm{~g} \mathrm{~kg}^{-1}$ range, i.e., from 330 to $390 \mathrm{~g} \mathrm{~kg}^{-1}$ (Figure 2). Seed yield ranged from minimum of 0.1 to maximum of $7.8 \mathrm{Mg} \mathrm{ha}^{-1}$. The mean seed yield was $3.8 \mathrm{Mg} \mathrm{ha}{ }^{-1}$, and $90 \%$ of the data ranged from 3 to $6 \mathrm{Mg}$ $\mathrm{ha}^{-1}$. Across different seed yield values, there was a slight change in both oil and protein concentration (Figure 3). Overall, oil concentration increased slowly at rate of $1.2 \mathrm{~g} \mathrm{~kg}^{-1}$ per $\mathrm{Mg}$ seed yield increase but protein concentration decreased at $1.3 \mathrm{~g} \mathrm{~kg}^{-1}$ per $\mathrm{Mg}$ seed yield increase. When relationships were investigated by study (as presented on insets, Figure 3A), 66\% of studies resulted in a slight negative trend for protein concentration as yield increased and the other $33 \%$ showed a slightly positive relationship for protein concentration and yield. This differed from the relationship between oil concentration and yield where 

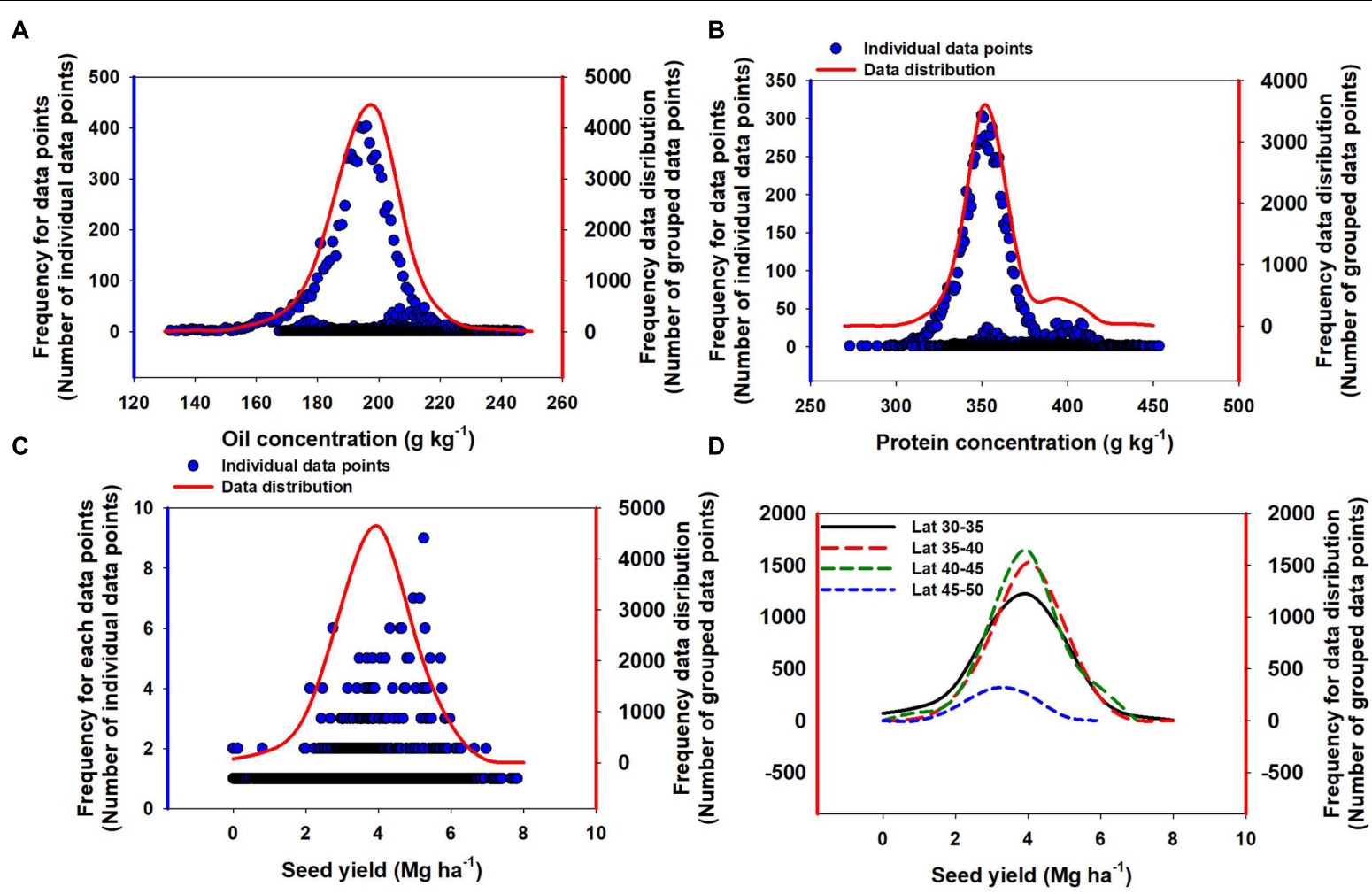

FIGURE 2 | Frequency distribution for individual data points and an overall distribution for soybean oil concentration (A), protein concentration (B), seed yield (C), and seed yield by latitude (D). Line data distributions were calculated by grouping values to the nearest whole number and adding the frequency of each of the grouped values to arrive at the frequency for the group.

$63 \%$ of studies supported a positive relationship and the other $37 \%$ displayed a slightly negative relationship. However, oil and protein concentration should not be confused with oil or protein yield (production per unit area). Both oil and protein yields increased in proportion to seed yield at rates of 198 and $350 \mathrm{~kg}$ per Mg seed yield increase, respectively (Figure 3B), a similar relation reported from a recently published different data set (Assefa et al., 2018). From the above relationship we can calculate that there was a $1.7 \mathrm{~kg}$ increase in protein yield for each $\mathrm{kg}$ oil yield increase. Thus, the overall ratio for soybean of protein- to oil-yield was 1.7. Often, a negative correlation between oil and protein concentration was reported. When pooling data across all our Es, there was no significant relationship between oil and protein concentration (Figure 3C). However, a tendency for a negative relationship between oil and protein concentration was observed when plotting data separately for each of the studies evaluated in the database (Figure 3C).

The reason why there was a positive seed-yield with proteinand oil- yield but a negative seed-yield to protein concentration relationships by $\mathrm{E}$ is because concentration is a relative measure and yield is an absolute measure. When seed-yield increase by $1 \mathrm{~kg}$, protein-yield increased (350 $\mathrm{g} \mathrm{kg}^{-1}$; Figure 3B) less than the mean protein concentration ( $357 \mathrm{~g} \mathrm{~kg}^{-1}$; Figure 2). From the oil perspective, for the same $1 \mathrm{~kg}$ seed yield increase, oil-yield increased (198 $\mathrm{g} \mathrm{kg}^{-1}$; Figure 3) slightly more proportionally than the mean oil concentration (195 $\mathrm{g} \mathrm{kg}^{-1}$; Figure 2).
The different trends for protein-yield and oil-yield relative to their mean concentrations in seed provide evidence for the negative relationship between oil and protein concentration by E. This positive relationship between protein- and oilyield with seed yield but a decline in protein concentration by $\mathrm{E}$ reported in this study is in line with results presented by Ray et al. (2006) and Rotundo and Westgate (2009). From a genetic standpoint, Chung et al. (2003) reported a negative correlation between protein concentration and yield, suggesting that the energetic cost associated with increased protein deposition is energetically costly than commonly assumed. When the data is analyzed across Es (not within an E), greater protein concentration was accompanied by also high oil concentration; while in Es with low protein, oil also presented low concentrations all relative to the high proteinoil Es. Therefore, protein-to-oil concentration relationships were negative within an $\mathrm{E}$ but no relationship or positive relationship tendencies across Es.

Environment alone explained significant variation in mean oil $\left(R^{2}=0.80\right)$ and protein $\left(R^{2}=0.85\right)$ concentrations, and seed yield $\left(R^{2}=0.74\right.$; Figure 4). The difference in concentration between the lowest and highest ranked Es (Figures 4A-C) were about $50 \mathrm{~g} \mathrm{~kg}^{-1}$ for oil and $110 \mathrm{~g} \mathrm{~kg}^{-1}$ for protein. The range between the lowest and highest average yielding E was about $4 \mathrm{Mg} \mathrm{ha}^{-1}$ for seed yield. However, yield and seed composition (protein and oil) rankings were not significantly correlated; neither oil 


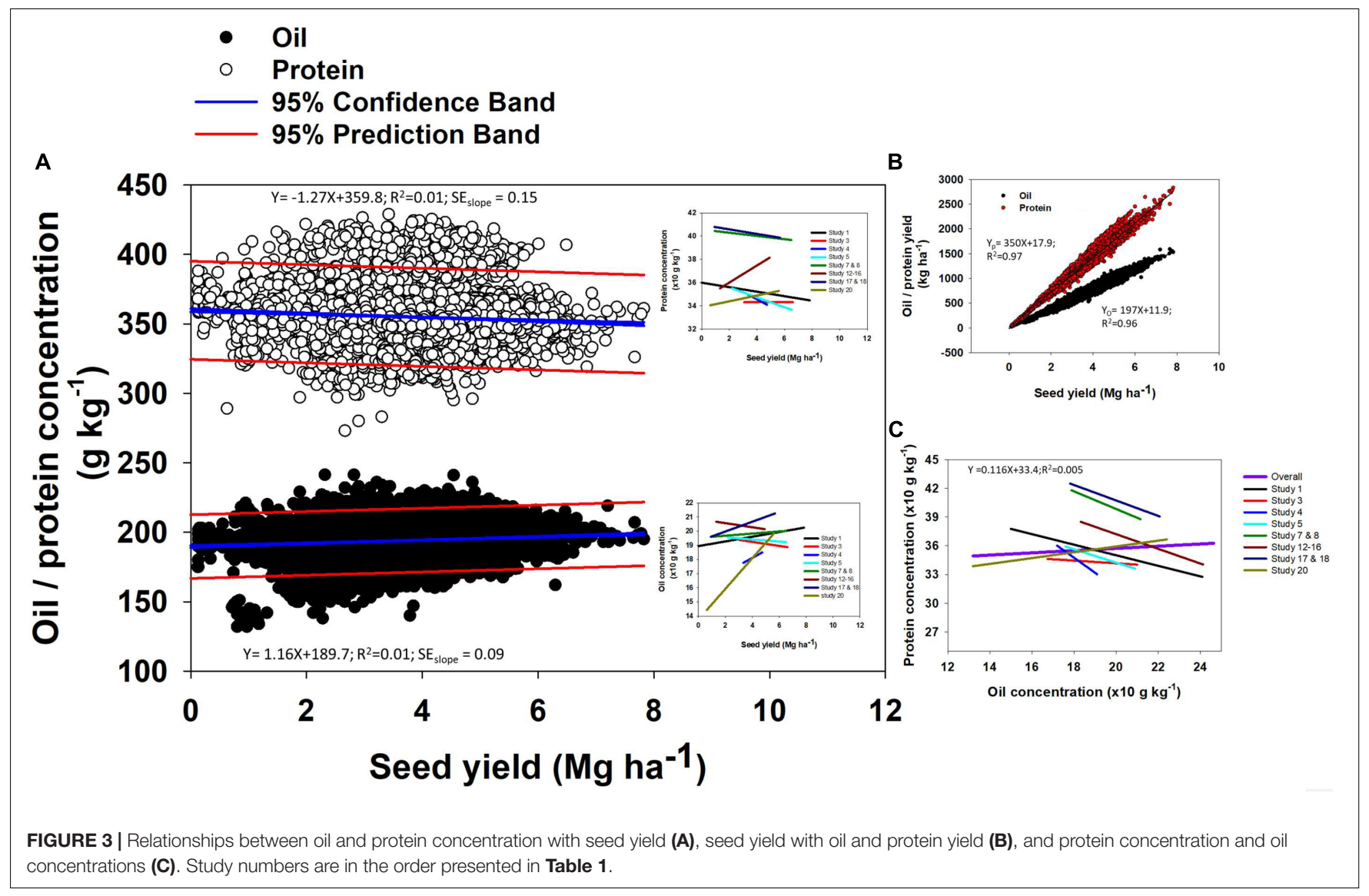

nor protein concentrations were linearly related to the yield ranking (Figure 4D).

Distribution of both oil and protein concentrations had a relatively narrow variation, primarily explained by the $\mathrm{E}$ (80-85\%). Likewise, E accounted for a major proportion of variation (74\%) for soybean seed yield. Environmental variation primarily encompasses differences in soil type and climate that affect plant growth, development, and yield formation. These results are generally in agreement with Mueller et al. (2012), highlighting the impact of weather affecting yields. Specifically, to soybean, Grieshop and Fahey (2001) reported that environmental conditions have great impact on seed composition. A synthesis analysis by Mourtzinis et al. (2018) also concluded that $68 \%$ of the variability in soybean yield in the United States was associated with variations in the E. Analysis of specific effects of environmental factors such as temperature and rainfall on seed composition and yield was not addressed in this study. Other studies have reported relationship between temperature or rainfall (water) with oil and protein content (Howell and Cartter, 1958; Piper and Boote, 1999; Pipolo et al., 2004; Kumar et al., 2006; Carrera et al., 2009; Ren et al., 2009; Rotundo and Westgate, 2009; Mourtzinis et al., 2017a). Our result, in general, suggest that Es with great seed yield have greater oil and protein yields, however, within an E oil concentration increase with yield while protein concentration decreases for possible reasons suggested above.

\section{Management}

Planting date is an important $\mathrm{M}$ factor affecting the overall length of the growing season, the time and developmental stage the crop is exposed to the $\mathrm{E}$, and resource availability during the cropping cycle. In a sense, the impact of planting date is connected to E and resources (nutrients, solar radiation, and water) which are vital to plant growth. Planting date did affect oil concentration and seed yield across latitudes but larger impacts were documented at northern latitudes, 40-45 N (Figure 5). In southern latitudes (30-35 N), mean oil concentration significantly declined with later planting dates at a rate of $-0.007 \%$ (planting week) ${ }^{-1}$ (Figure 5A). In mid latitudes $(35-40 \mathrm{~N})$, mean oil concentration also declined significantly as planting was delayed at a rate of $-0.011 \%$ (planting week) $^{-1}$ (Figure 5B), representing a $36 \%$ larger reduction in mean oil concentration relative to the southern latitudes (30-35 N). In northern latitudes (40-45 N), a sharper, significant decline in mean oil concentration was documented as planting date was delayed at an overall rate of $-0.058 \%$ (planting week) $^{-1}$ (Figure 5C), an $88 \%$ larger impact of planting date on oil for this latitude relative to the southern latitudes $(30-35 \mathrm{~N})$.

Protein concentration was not significantly affected in most of the latitude groups (Figures 5D,E), except for the northern latitude range $40-45 \mathrm{~N}$, presenting a significant decline for overall mean protein concentration at a rate of $-0.027 \%$ planting week $^{-1}$ (Figure 5F). For seed yield, mean yield was not affected 


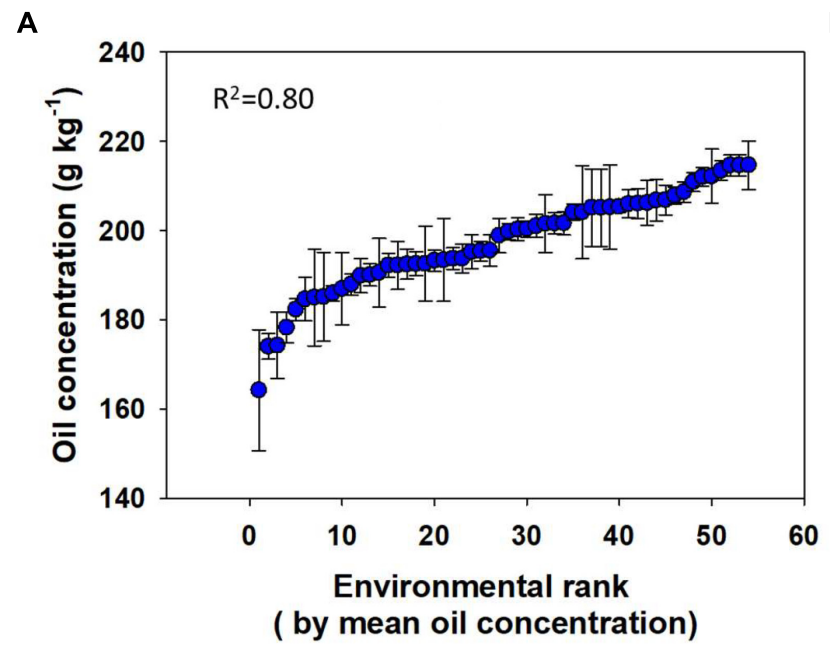

C

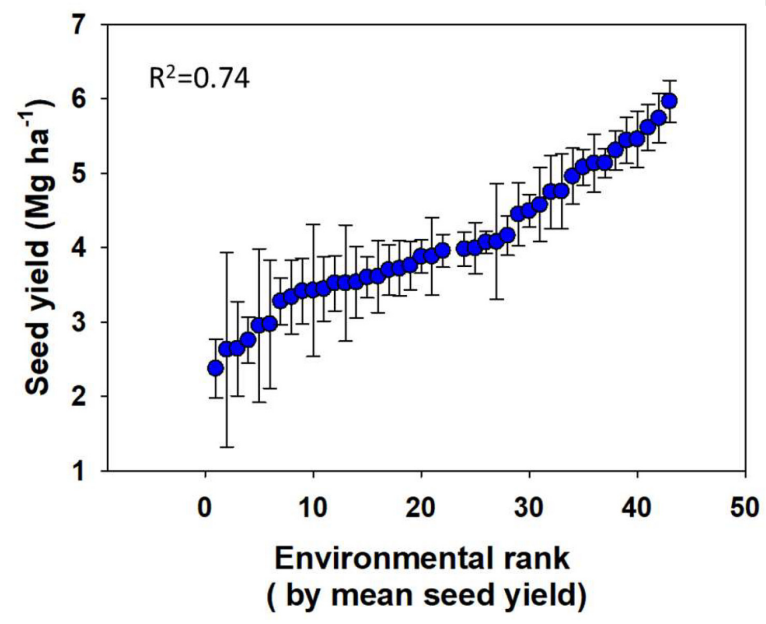

B

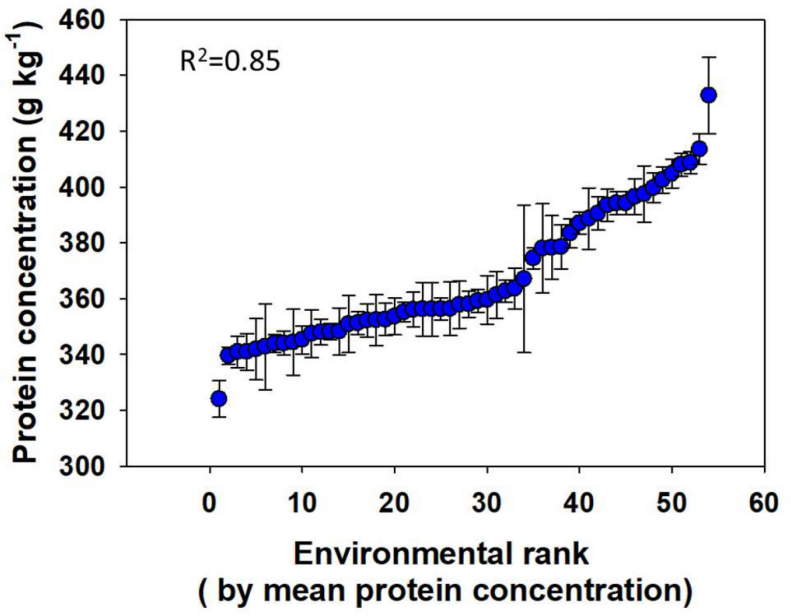

D

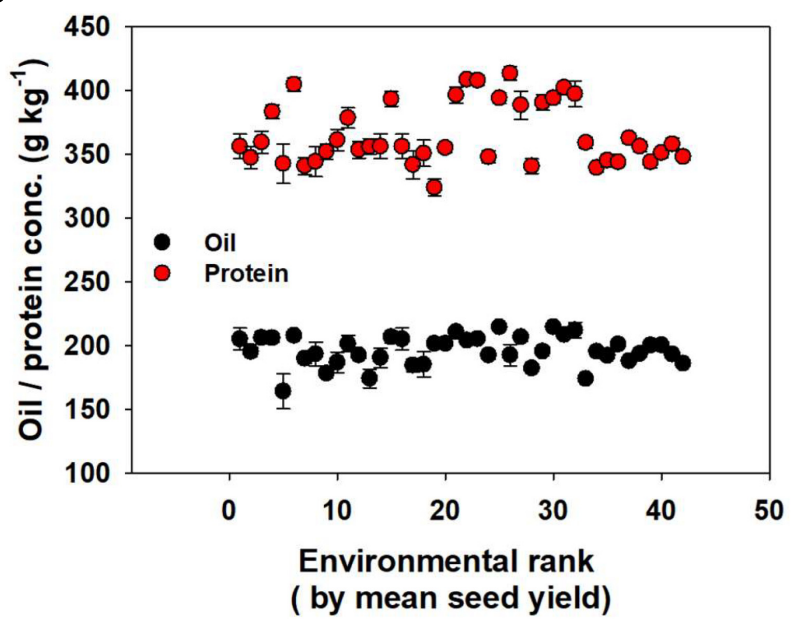

FIGURE 4 | Variation in oil concentration (A), protein concentration (B), and seed yield (C) across environments each ranked with respective variables and oil and protein concentration (D) across Es ranked with mean seed yield.

by planting date at the southern latitude range (30-35 N), but a significant negative impact was observed for the mid-latitude range $(35-40 \mathrm{~N})$ at a rate of $-0.010 \mathrm{Mg} \mathrm{ha}^{-1}$ (planting week) ${ }^{-1}$ (Figure $5 \mathbf{H}$ ) and for the northern latitudes $(40-45 \mathrm{~N})$ at a rate of $-0.041 \mathrm{Mg} \mathrm{ha}^{-1}$ (planting week) ${ }^{-1}$. The latter latitude range presented a larger significant impact on yield as planting date was delayed (Figure 5I). Mean seed yield values tended to decline with planting after 145 DOY in both mid- and high-latitude ranges.

This lack of yield response to planting date in lower latitudes is in contrast with the study by Egli and Cornelius (2009), that found a rate of decline with delay in planting date of $0.7 \%$ in the Midwest, and 1.1-1.2\% in the Midsouth and Deep South. Our result on lack of yield response in lower latitude also differs from the conclusions from Salmeron et al. (2014) and Salmeron et al. (2016), which are based on a large subset of data from this paper but considered planting data effect by MG and found significant yield reductions when planting date was delayed. In the analysis by Salmeron et al. (2016), yield showed a quadratic or negative linear response to day of planting depending on the location and soybean maturity. Delaying planting date from midMay to early June decreased yields by 0.09 to $1.69 \%$ per day of delay in planting date (approximately 0.003 to $0.414 \mathrm{Mg} \mathrm{ha}^{-1}$ week $^{-1}$ ) (Salmeron et al., 2016). Here, we looked at the main effect of planting date (not interaction with MG) and the lack of response to planting date in the lower latitudes perhaps is result of averaging effect over many MGs that responded differently at different planting windows.

In summary, late planting date negatively impacted oil concentration and seed yield. The impact of planting date on oil or seed yield, was moderate at the southern latitude $(30-35 \mathrm{~N})$ compared to the northern latitudes $(40-45 \mathrm{~N})$. Protein concentration was only significantly affected by late planting date for the northern-latitude range (40-45 N). In southern latitudes, there is a wider "window" for planting due to longer frost free time period and generally preferred growing condition. Significant decline in oil concentration but not protein concentration did not mean protein concentration is not 


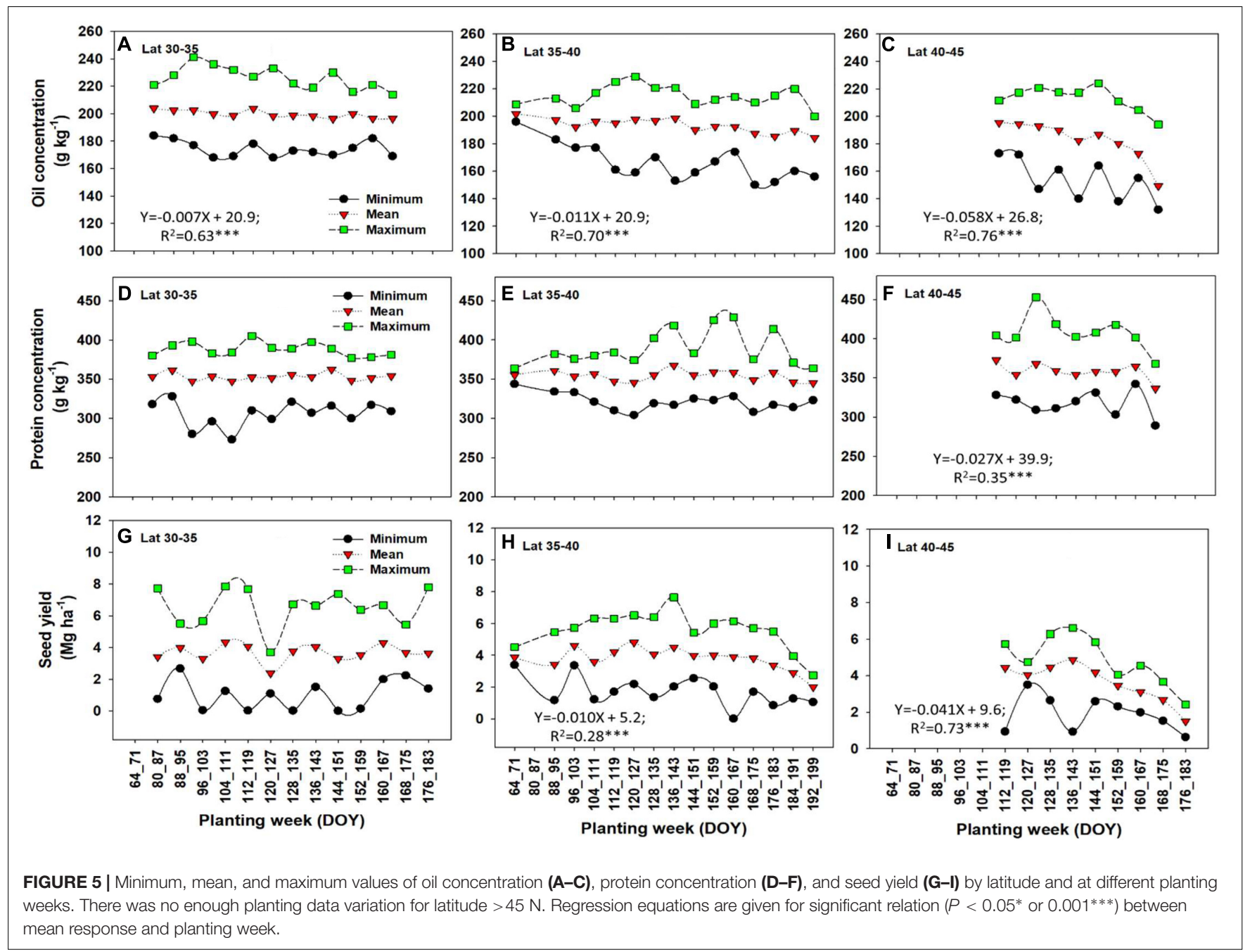

negatively affected. Since concentration is a relative measure, if oil content increases faster than protein content when yield increase, then when seed yield decreases due to delayed planting date, oil content should be potentially decreasing faster than protein content and therefore the decrease in oil is more significant than protein concentration. Planting dates are important in northern latitudes due to the shorter growing season, and a similar conclusion has been documented for corn planting date range across latitudes in the United States (Long et al., 2017). The importance of planting date to soybean seed composition and yield was reported (Jaureguy et al., 2013; Bellaloui et al., 2015; Mourtzinis et al., 2017a) but with conflicting results. The unique aspect of this study regarding planting date is that our report covers trends with data from multiple sites across latitudes and planting weeks within each latitude. In a structured planting date studies, results are presented by $\mathrm{E}$ and relative to early and late scheduled planting dates in each study. In most planting date studies, what is early and late planting is subjective and usually defined in relative to planting dates of the study each year. Within a planting date study, what is early and what is late differs by year to the extent that the late planting date 1 year may become early planting date in another year. The advantage of this meta-analysis is the ability to detect the overall trend across studies regardless of year-to-year variability. Our limitation is in dissecting planting date effect by other interacting factors such as varieties or maturity, which vary by studies included in the analysis.

Crop management factors such as no-till, seed treatments, foliar $\mathrm{N}$, fungicide and insecticide applications, and rotation, by improving crop growing conditions through conserving or suppling water and nutrients or improving soil physicochemical conditions and protecting the crop from disease, had an overall positive effect on both oil and protein concentrations (Figure 6). Some of these $\mathrm{M}$ factors (no-till, seed treatment, foliar N) which showed a positive impact on seed composition did not necessarily affect yields relative to their conventional production techniques. Overall seed yield did not seem to benefit from most of these improved crop $M$ systems except for crop rotation and foliar fungicide and insecticide applications. Similar conclusions on a positive impact of rotation and no effect from seed treatment were reported by Mourtzinis et al. (2017b). The positive impact of diverse rotation for seed composition and 


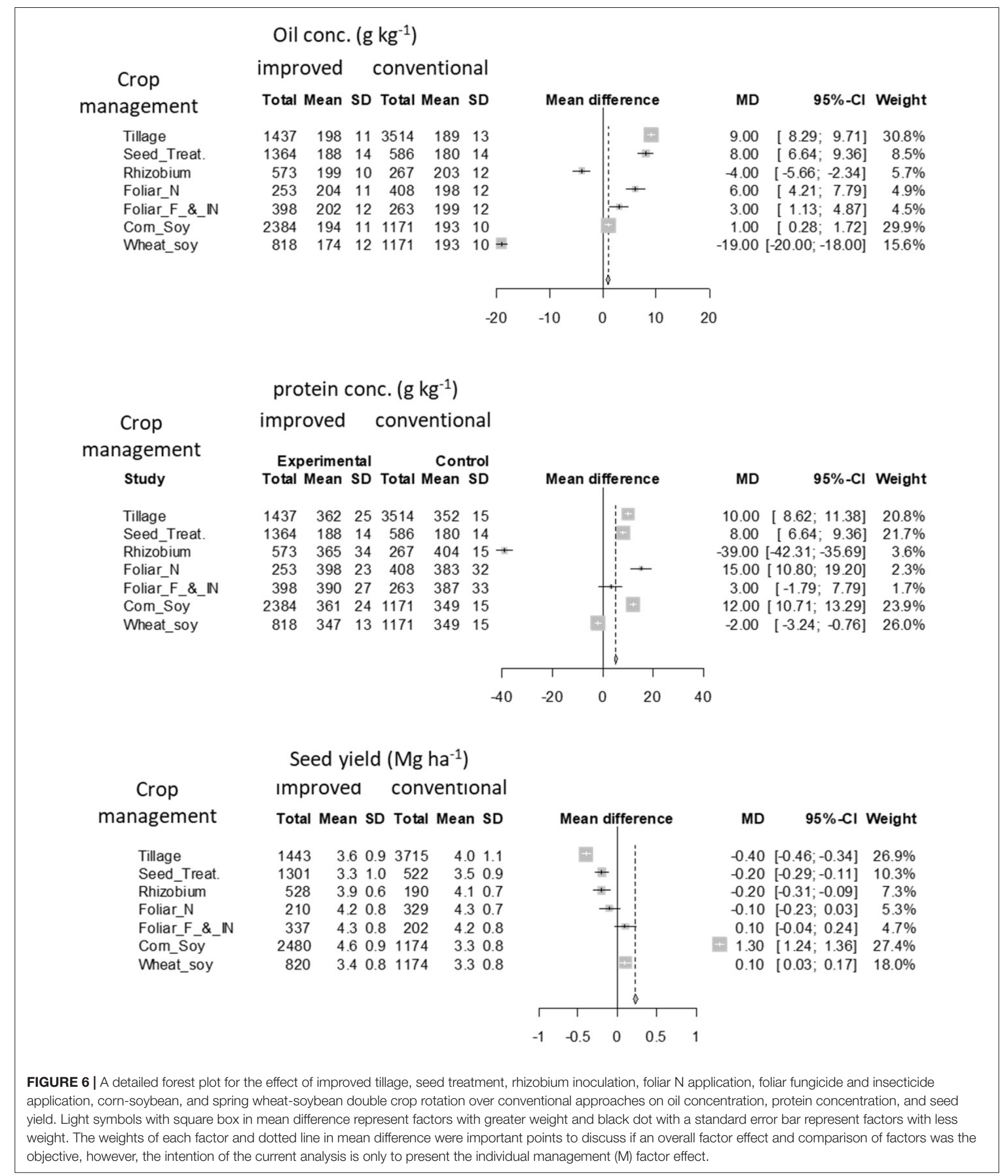

yield is evident for soybean and other crops (Riedell et al., 2009; Bellaloui et al., 2014). A divergence in soil microbial population between mono-cropping and rotation was among the main mechanisms for rotation positively affecting crop growth, yield, and seed composition in oil seed rape (Brassica napus; Hilton et al., 2013). A mixed response to tillage treatments 
by year of experiment was reported by Singer et al. (2008). Research on the effect of $M$ factors such as tillage on seed composition is limited. This analysis calls for the need of investigations on the most relevant $M$ factors and mechanisms impacting seed composition to better understand the interaction between $\mathrm{G} \times \mathrm{E} \times \mathrm{M}$.

\section{Nitrogen Input}

Oil and protein concentrations responded differently to fertilizer $\mathrm{N}$ input relative to seed yield (Figure 7). Exceedance probability calculates the probability of obtaining oil, protein, or yield exceeding a value for those parameters at each $\mathrm{N}$ rate category. The exceedance probability for each level of oil concentration increases when $\mathrm{N}$ inputs increased from 0 to $10-50 \mathrm{~kg} \mathrm{ha}^{-1}$ but decreased as $\mathrm{N}$ fertilization increases greater than $50 \mathrm{~kg}$ $\mathrm{ha}^{-1}$ (Figure 7A). Therefore, there was a higher probability of obtaining greater oil concentration with $\mathrm{N}$ application ranging from 10 -to- $50 \mathrm{~kg} \mathrm{~N} \mathrm{ha}^{-1}$ than when $\mathrm{N}$ fertilization is above $50 \mathrm{~kg}$ $\mathrm{N} \mathrm{ha}^{-1}$. For example, there was a $20 \%$ exceedance probability of obtaining more than $200 \mathrm{mg} \mathrm{kg}^{-1}$ oil concentration with the fertilizer $\mathrm{N}$ range $100-150 \mathrm{~kg} \mathrm{~N}^{-1}$ but a $70 \%$ chance of getting similar oil values for the $\mathrm{N}$ fertilization range $10-50 \mathrm{~kg}$ $\mathrm{N}$ ha ${ }^{-1}$. Similar to oil concentration, the exceedance probability for protein concentration widens when $\mathrm{N}$ application increased from 0 to $10-50 \mathrm{~kg} \mathrm{~N}^{-1}$ and decreased substantially as $\mathrm{N}$ application increased above $10-50 \mathrm{~kg} \mathrm{~N}^{-1}$ (Figure 7B). It is worth highlighting that the exceedance probability when zero-N was applied is somewhat similar at the $50 \%$ probability level to the model when more than $150 \mathrm{~kg} \mathrm{~N} \mathrm{ha}^{-1}$ is applied to soybeans, obtained both a probability for mean protein concentration slightly above of 36\% (Figure $7 \mathbf{B}$ ). The exceedance probability for seed yield, on the other hand, did not significantly change when $\mathrm{N}$ input increased from 0 to $100 \mathrm{~kg}$ $\mathrm{N} \mathrm{ha}^{-1}$, but expanded when fertilizer $\mathrm{N}$ application increased from the 0 to $100 \mathrm{~kg} \mathrm{~N} \mathrm{ha}{ }^{-1}$ to the $100-150 \mathrm{~kg} \mathrm{~N} \mathrm{ha}^{-1}$ range (Figure $7 \mathrm{C}$ ).

A recent synthesis analysis on the impact of the rate, timing, and source of $\mathrm{N}$ fertilizer applied to soybean found that these factors contributed to less than one percent of the variation in seed yield (Mourtzinis et al., 2018). The yield benefits of smaller amounts of fertilizer as a starter (Osborne and Riedell, 2006; Gai et al., 2017) or full-N late application at R3-R4 stage (Ortez et al., 2018) were reported in the scientific literature. A positive impact of application of fertilizer on yield and seed composition, mainly in a high yielding $\mathrm{E}$ was reported by $\mathrm{La}$ Menza et al. (2017). Ray et al. (2006) reported a positive impact of application of higher rates of $\mathrm{N}$ on seed, protein, and oil yield but a decrease in protein concentration and protein to oil ratio. In a meta-analysis, Rotundo and Westgate (2009) reported a positive effect of $\mathrm{N}$ additions on seed protein concentration and more importantly on protein content $\left(\mathrm{mg} \mathrm{seed}^{-1}\right)$ for soybean. In a recently published study, Ortez et al. (2018) indicated that for soybean yield response to $\mathrm{N}$ fertilization is not strictly dependent on the yield $\mathrm{E}$, but other factors influencing soil $\mathrm{N}$ supply and $\mathrm{N}$ fixation interaction. The above cited results have mixed message regarding impact of $\mathrm{N}$ application to seed yield and quality composition, demonstrating the complex influence of $\mathrm{E}$ (study)

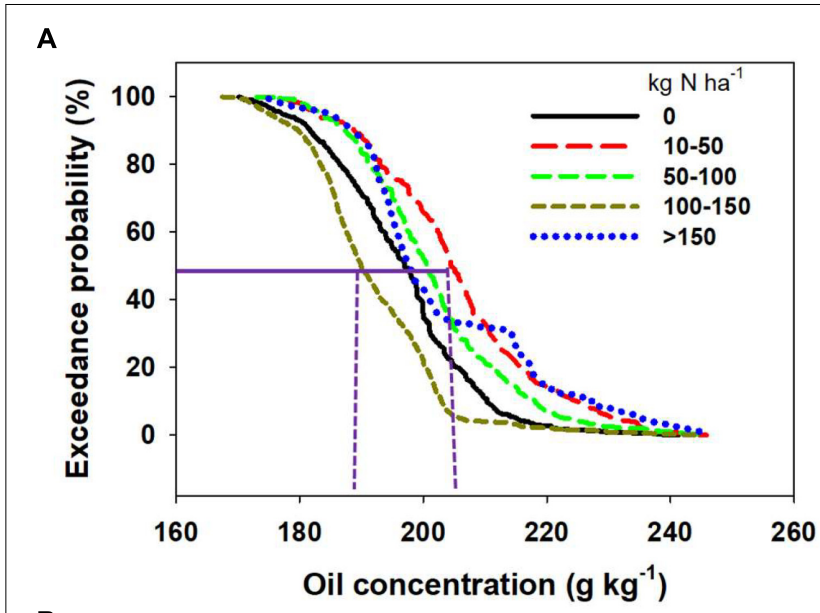

B

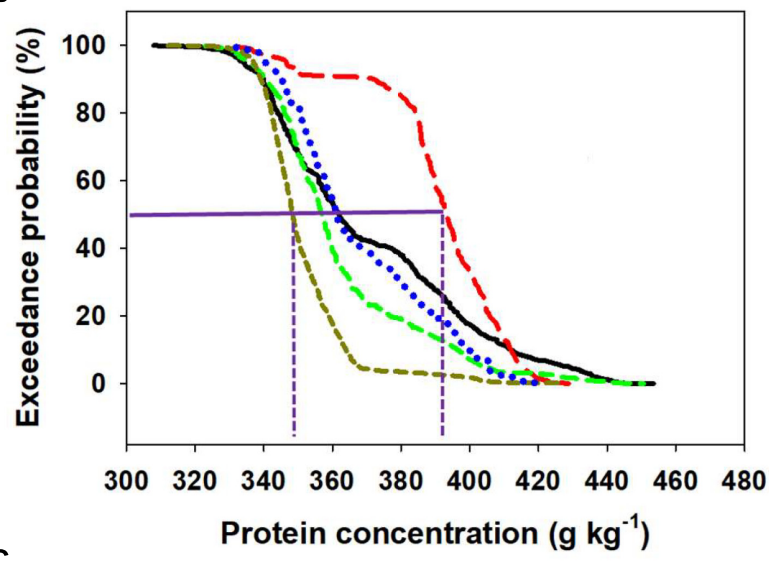

C

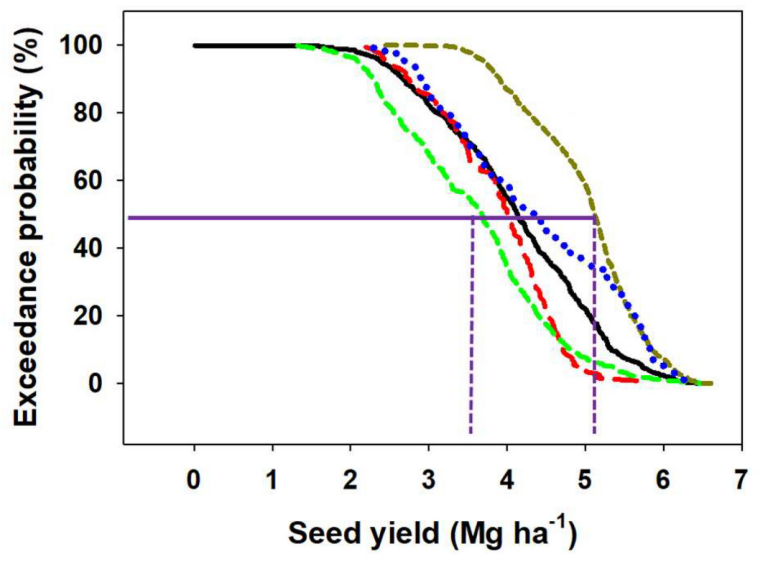

FIGURE 7 | Exceedance probabilities for oil concentration (A), protein concentration (B), and seed yield (C) of soybean at different $\mathrm{N}$ rate. Exceedance probability here is defined as the probability (indicated in the $y$-axis) of obtaining oil, protein, or yield exceeding the indicated value (in the $x$-axis) for each fertilizer $\mathrm{N}$ rate category.

on the effect of this factor on the response variables. Probability of documenting yield gains with $\mathrm{N}$ fertilization will increase in Es where both $\mathrm{N}$ fixation and soil $\mathrm{N}$ supply are not capable of satisfying overall soybean plant $\mathrm{N}$ demand (e.g., Wilson et al., 2014; La Menza et al., 2017; Ortez et al., 2018). 

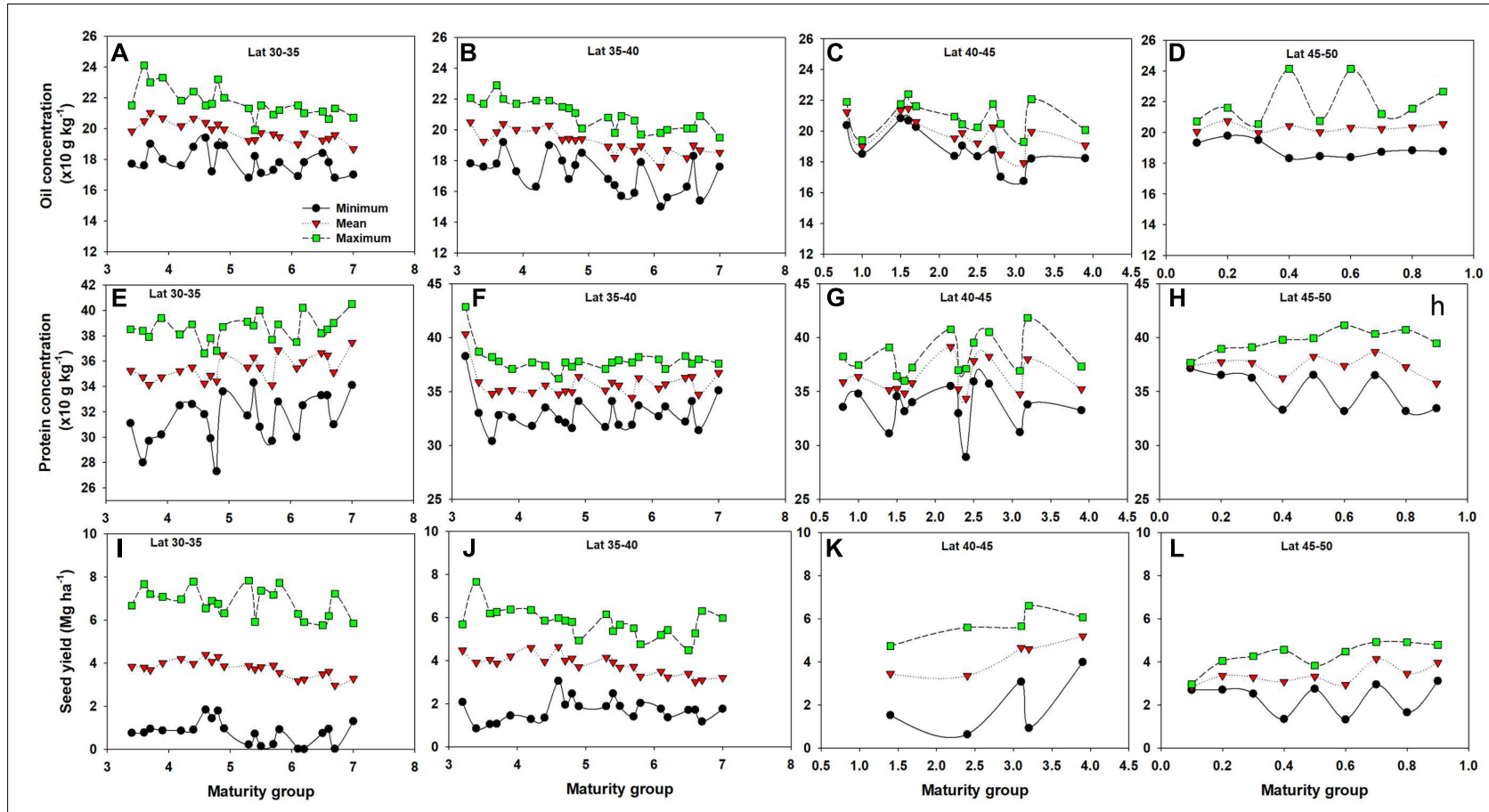

FIGURE 8 | Minimum, mean, and maximum values of oil concentration (A-D), protein concentration (E-H), and seed yield (I-L) by latitude and different varieties maturity groups (MG).

\section{Genetics (Maturity Group)}

Based on their photoperiod (day length) requirement soybean varieties are subdivided into different MGs. In southern latitudes $(30-40 \mathrm{~N})$, oil concentration tended to slightly decline as soybean MG increased, with protein portraying an opposite trend, primarily in the 30-35 N latitude, even though both were not statistically significant trends (Figure 8). There was also no significant difference among MGs in seed yield across all latitude groups. Evidence of genetic variability in soybean seed composition and yield is plentiful (TeKrony et al., 1984; Bajaj et al., 2008; Mourtzinis et al., 2017a,b). Our literature review on the effect of MG on oil and protein concentration found less published research, and few of the results presented in the scientific literature suggest a minor impact of $\mathrm{MG}$ on oil and protein relative to $M$ such as planting date (Mourtzinis et al., 2017a).

In summary, E (e.g., temperature, solar radiation, precipitation) (Carrera et al., 2011; Rotundo et al., 2016) produced a significant impact on soybean seed yield and quality. $\mathrm{M}$ factors such as crop rotation and planting date had consistent positive or negative relation, whereas $\mathrm{N}$ application and other $\mathrm{M}$ factors have mixed effect one for seed composition and different for seed yield (Rotundo and Westgate, 2009; Bellaloui et al., 2015; Ortez et al., 2018). Other have reported the impact of G (e.g., variety, MG, plant traits) (Dardanelli et al., 2006; Bellaloui et al., 2009), in interaction with the E but this study only focused on main effects of E, M, and G. A detailed review chapter published by Bellaloui et al. (2011) provided a synthesis on the effects of $\mathrm{G} \times \mathrm{E} \times \mathrm{M}$ on soybean seed composition. The same authors concluded that a main scientific research gaps is related to studying the physiological mechanisms related to the variation on seed composition and the $\mathrm{G} \times \mathrm{E} \times \mathrm{M}$ interaction.

\section{CONCLUSION}

This study provides a comprehensive analysis of $\mathrm{G}, \mathrm{M}$, and $\mathrm{E}$ factors influencing soybean yield quantity and quality across the United States Corn Belt. Because of the geographic coverage and numerous data points, it can serve as a baseline upon which future studies can design improved practices or measure future improvements in yields and quality. Multiple factors affect soybean seed composition and yield. E is a dominant factor for the significant variability in seed composition and yield $\left(R^{2}>70 \%\right)$. Among the impacts of crop M factors are: (i) negative effect of late planting date on oil concentration and yield in northern latitude (40-45 N); (ii) positive impact of crop rotation for both seed composition and yield; and (iii) mixed impacts of some $\mathrm{M}$ factors such as no-till, seed treatment, foliar nutrient and fungicide applications on seed composition. Application of $\mathrm{N}$ in smaller amount (less than $50 \mathrm{~kg} \mathrm{~N} \mathrm{ha}^{-1}$ ) improved seed composition but seed yield was improved when $\mathrm{N}$ applications were above $100 \mathrm{~kg} \mathrm{~N} \mathrm{ha}^{-1}$. MG differences in seed composition were not significant, but declining trend in oil and an increase in protein concentrations with increasing soybean MG were observed in southern latitudes (30-35 N). Exploring the $\mathrm{G} \times \mathrm{E} \times \mathrm{M}$ interaction is critical to better understand the current research gap and to move forward our science on this topic. 


\section{DATA AVAILABILITY}

All datasets generated for this study are included in the manuscript and/or the supplementary files.

\section{AUTHOR CONTRIBUTIONS}

YA, IC, and DD contributed to conception or design of the work. LP, MS, SN, SC, PK, SA, ML, FB, HK, LL, JG, SC, CS, JO, BG, GK, MS, KT, and RL collected the data. YA and IC contributed in data analysis and interpretation. YA, IC, LP, HK, SN, and CS drafted the article. LP, MS, SN, SC, PK, SA, ML, FB, HK, LL, JG, SC, CS, JO, BG, GK, MS, KT, RL, and IC contributed in critical revision of the article. IC gave final approval of the version to be published.

\section{REFERENCES}

Assefa, Y., Bajjalieh, N., Archontoulis, S., Casteel, S., Davidson, D., Kovács, P., et al. (2018). Spatial characterization of soybean yield and quality (Amino Acids, Oil, and Protein) for United States. Sci. Rep. 8:14653. doi: 10.1038/s41598-01832895-0

Bajaj, S., Chen, P., Longer, D. E., Hou, A., Shi, A., Ishibashi, T., et al. (2008). Planting date and irrigation effects on seed composition of early-maturing soybean in the mid-South USA. J. N. Seeds 9, 212-233. doi: 10.1080/15228860802228800

Bellaloui, N., Abbas, H. K., Gillen, A. M., and Abel, C. A. (2009). Effect of glyphosate-boron application on seed composition and nitrogen metabolism in glyphosate-resistant soybean. J Agric. Food Chem. 57, 9050-9056. doi: 10.1021/ jf901801z

Bellaloui, N., Bruns, H. A., Abbas, H. K., Mengistu, A., Fisher, D. K., and Reddy, K. N. (2015). Agricultural practices altered soybean seed protein, oil, fatty acids, sugars, and minerals in the Midsouth USA. Front. Plant Sci. 6:31. doi: 10.3389/fpls.2015.00031

Bellaloui, N., Bruns, H. A., Gillen, A. M., Abbas, H. K., Zablotowicz, R. M., Mengistu, M., et al. (2010). Soybean seed protein, oil, fatty acids, and mineral composition as influenced by soybean-corn rotation. Agric. Sci. 1, 102-109. doi: 10.4236/as.2010.13013

Bellaloui, N., and Mengistu, A. (2008). Seed composition is influenced by irrigation regimes and cultivar. Irrig. Sci. 26, 261-268. doi: 10.1007/s00271-007-0091-y

Bellaloui, N., Reddy, K. N., Bruns, A., Gillen, A. M., Mengistu, A., Zobio-le, L. H. S., et al. (2011). "Soybean seed composition and quality: interactions of environment, genotype, and management practices," in Soybeans: Cultivation, Uses and Nutrition, ed. J. Maxwell (New York, NY: Nova Science Publishers), $1-42$.

Bellaloui, N., Stetina, S., and Molin, W. (2014). Soybean seed nutrition as affected by cotton, wheat, and fallow rotation. Food Nutr. Sci. 5, 1605-1619. doi: 10. 4236/fns.2014.516173

Boydak, E., Alpaslan, M., Hayta, M., Gercek, S., and Simsek, M. (2002). Seed composition of soybeans grown in the Harran region of Turkey as affected by row spacing and irrigation. J. Agric. Food Chem. 50, 4718-4720. doi: 10.1021/ jf0255331

Carrera, C., Martínez, M. J., Dardanelli, J., and Balzarini, M. (2009). Water deficit effect on the relationship between temperature during the seed fill period and soybean seed oil and protein concentrations. Crop Sci. 49, 990-998. doi: 10. 2135/cropsci2008.06.0361

Carrera, C. S., Reynoso, C. M., Funes, G. J., Martínez, M. J., Dardanelli, J., and Resnik, S. L. (2011). Amino acid composition of soybean seeds as affected by climatic variables. Pesqui. Agropecu. Bras. 46, 1579-1587. doi: 10.1590/S0100204X2011001200001

Cartter, J. L., and Hopper, T. H. (1942). Influence of Variety, Environment, and Fertility Level on the Chemical Composition of Soybean Seed, USDA Technical Bulletin 787. Washington, DC: U.S. Government Printing Office.

\section{FUNDING}

The United Soybean Board (USB Projects\#2234 and \#1820152-0108), Mid-South Soybean Board, Mississippi Soybean Promotion Board, Nebraska Soybean Board, South Dakota Soybean Research and Promotion and Council, Illinois AES project ILLU-802-344, and K-State Research and Extension (KSRE), provided funding to support this synthesis analysis. This was contribution no. 19-142-J from the Kansas Agricultural Experiment Station.

\section{ACKNOWLEDGMENTS}

The researchers thank all the students, technicians, and others who helped with the individual studies summarized in this regional soybean database.

Chung, J., Babka, H. L., Graef, G. L., Staswick, P. E., Lee, D. J., Cregan, P. B., et al. (2003). The seed protein, oil, and yield QTL on soybean linkage Group I. Crop Sci. 43, 1053-1067. doi: 10.2135/cropsci2003.1053

Dardanelli, J. L., Balzarinic, M., Martínez, M. J., Cuniberti, M., Resnik, S., Ramunda, S. F., et al. (2006). Soybean maturity groups, environments, and their interaction define mega-environments for seed composition in Argentina. Crop Sci. 46, 1939-1947. doi: 10.2135/cropsci2005.12-0480

Egli, D. B., and Cornelius, P. L. (2009). A regional analysis of the response of soybean yield to planting date. Agron. J. 101, 330-335. doi: 10.2134/agronj2008. 0148

Elsheikh, E. A. E., Salih, S. S. M., Elhussein, A. A., and Babiker, E. E. (2009). Effects of intercropping, Bradyrhizobium inoculation and chicken manure fertilisation on the chemical composition and physical characteristics of soybean seed. Food Chem. 112, 690-694. doi: 10.1016/j.foodchem.2008.06.037

Gai, Z., Zhang, J., and Caifeng, L. (2017). Effects of starter nitrogen fertilizer on soybean root activity, leaf photosynthesis and grain yield. PLoS One 12:e0174841. doi: 10.1371/journal.pone.0174841

Goldflus, F., Ceccantini, M., and Santos, W. (2006). Amino acid content of soybean samples collected in different Brazilian states - Harvest 2003/2004. Braz. J. Poult. Sci. 8, 105-111. doi: 10.1590/S1516-635X2006000200006

Grieshop, C. M., and Fahey, G. C. Jr. (2001). Comparison of quality characteristics of soybeans from Brazil, China, and the United States. J. Agric. Food Chem. 49, 2669-2673. doi: 10.1021/jf0014009

Ham, G. E., Liener, I. E., Evans, S. D., Frazier, R. D., and Nelson, W. W. (1975). Yield and composition of soybean seed as affected by $\mathrm{N}$ and S fertilization. Agron. J. 67, 293-297. doi: 10.2134/agronj1975.00021962006700030004x

Haq, M., and Mallarino, A. P. (2005). Response of soybean grain oil and protein concentrations to foliar and soil fertilization. Agron. J. 97, 910-918. doi: 10 2134/agronj2004.0215

Hilton, S., Bennett, A. J., Keane, G., Bending, G. D., Chandler, D., Stobart, R. et al. (2013). Impact of shortened crop rotation of oilseed rape on soil and rhizosphere microbial diversity in relation to yield decline. PLoS One 8:e59859. doi: 10.1371/journal.pone.0059859

Howell, R. W., and Cartter, J. L. (1958). Physiological factors affecting composition of soybeans: II. Response of oil and other constituents of soybeans to temperature under controlled conditions. Agron. J. 50, 664-667. doi: 10.2134/ agronj1958.00021962005000110007x

Jaureguy, L. M., Rodriguez, F. L., Zhang, L., Chen, P., Brye, K., Oosterhuis, D., et al. (2013). Planting date and delayed harvest effects on soybean seed composition. Crop Sci. 53, 2162-2175. doi: 10.2135/cropsci2012.12.0683

Kumar, V., Rani, A., Solanki, S., and Hussain, S. M. (2006). Influence of growing environment on the biochemical composition and physical characteristics of soybean seed. J. Food Comp. Anal. 19, 188-195. doi: 10.1016/j.jfca.2005.06.005

La Menza, C. N., Monzon, J. P., Specht, J. E., and Grassini, P. (2017). Is soybean yield limited by nitrogen supply? Field Crops Res. 213, 204-212. doi: 10.1016/j. fcr.2017.08.009 
Lewis, S., and Clarke, M. (2001). Forest plots: trying to see the wood and the trees. BMJ 322, 1479-1480. doi: 10.1136/bmj.322.7300.1479

Long, N. V., Assefa, Y., Schwalbert, R., and Ciampitti, I. A. (2017). Maize yield and planting date relationship: a synthesis-analysis for US high-yielding contestwinner and field research data. Front. Plant Sci. 8:2106. doi: 10.3389/fpls.2017. 02106

Maestri, D. M., Labuckas, D. O., Meriles, J. M., Lamarque, A. L., Zygadlo, J. A., and Guzman, C. A. (1998). Seed composition of soybean cultivars evaluated in different regions. J. Sci. Food Agric. 77, 494-498. doi: 10.1002/(SICI)10970010(199808)77:4<494::AID-JSFA69>3.0.CO;2-B

Mourtzinis, S., Gaspar, A. P., Naeve, S. L., and Conley, S. P. (2017a). Planting date, maturity, and temperature effects on soybean seed yield and composition. Agron. J. 109, 2040-2049. doi: 10.2134/agronj2017.05.0247

Mourtzinis, S., Marburger, D., Gaska, J., Diallo, T., Lauer, J., and Conley, S. (2017b). Corn and soybean yield response to tillage, rotation, and nematicide seed treatment. Crop Sci. 57, 1704-1712. doi: 10.2135/cropsci2016.09.0792

Mourtzinis, S., Kaur, G., Orlowski, J. M., Shapiro, C. A., Lee, C. D., Wortmann, C., et al. (2018). Soybean response to nitrogen application across the United States: a synthesis-analysis. Field Crops Res. 215, 74-82. doi: 10.1016/j.fcr.2017. 09.035

Mueller, N. D., Gerber, J. S., Johnston, M., Ray, D. K., Ramankutty, N., and Foley, J. A. (2012). Closing yield gaps through nutrient and water management. Nature 490, 254-257. doi: 10.1038/nature11420

Nakasathien, S., Israel, D. W., Wilson, R. F., and Kwanyuen, P. (2000). Regulation of seed protein concentration in soybean by supra-optimal nitrogen supply. Crop Sci. 40, 1277-1284. doi: 10.2135/cropsci2000.4051277x

Ortez, O. A., Salvagiotti, F., Enrico, J. M., Prasad, P. V. V., Armstrong, P., and Ciampitti, I. A. (2018). Exploring nitrogen limitation for historical and modern soybean. Genotypes. Agron. J. 110, 1-11. doi: 10.2134/agronj2018.04. 0271

Osborne, S. L., and Riedell, W. E. (2006). Starter nitrogen fertilizer impact on soybean yield and quality in the Northern Great Plains. Agron. J. 98, 1569-1574. doi: 10.2134/agronj2006.0089

Piper, E. L., and Boote, K. J. (1999). Temperature and cultivar effects of soybean seed oil and protein concentration. J. Am. Oil Chem. Soc. 76, 1233-1241. doi: 10.1007/s11746-999-0099-y

Pipolo, A. E., Sinclair, T. R., and Camara, G. M. S. (2004). Effects of temperature on oil and protein concentration in soybean seed cultured in vitro. Ann. Appl. Biol. 144, 71-76. doi: 10.1111/j.1744-7348.2004.tb00318.x

R Development Core Team (2012). R: A Language and Environment for Statistical Computing. Vienna: R Foundation for Statistical Computing.

Rao, M. S. S., Mullinix, B. G., Rangappa, M., Cebert, E., Bhagsari, A. S., Sapra, V. T., et al. (2002). Genotype $\times$ environment interactions and yield stability of food-grade soybean genotypes. Agron. J. 94, 72-80. doi: 10.2134/agronj2002. 0072

Ray, J. D., Fritschi, F. B., and Heatherly, L. G. (2006). Large applications of fertilizer $\mathrm{N}$ at planting affects seed protein and oil concentration and yield in the early soybean production system. Field Crops Res. 99, 67-74. doi: 10.1016/j.fcr.2006. 03.006

Ren, C., Bilyeu, K. D., and Beuselinck, P. (2009). Composition, vigor, and proteome of mature soybean seeds developed under high temperature. Crop Sci. 49, 1010-1022. doi: 10.2135/cropsci2008.05.0247

Riedell, W. E., Pikul, J. L., Jaradat, A. A., and Schumacher, T. E. (2009). Crop rotation and nitrogen input effects on soil fertility, maize mineral nutrition, yield, and seed composition. Agron. J. 101, 870-879. doi: 10.1371/journal.pone. 0082147

Robinson, A. P., Conley, S. P., Volenec, J. J., and Santini, J. B. (2009). Analysis of high yielding, early-planted soybean in Indiana. Agron. J. 101, 131-139. doi: 10.2134 /agronj2008.0014x

Rotundo, J. L., Miller-Garvin, J. E., and Naeve, S. L. (2016). Regional and temporal variation in soybean seed protein and oil across the United States. Crop Sci. 56, 797-808. doi: 10.2135/cropsci2015.06.0394

Rotundo, J. L., and Westgate, M. E. (2009). Meta-analysis of environmental effects on soybean seed composition. Field Crops Res. 110, 147-156. doi: 10.1016/j.fcr. 2008.07.012

Rowntree, S. C., Suhre, J. J., Weidenbenner, N. H., Wilson, E. W., Davis, V. M., Naeve, S. L., et al. (2013). Genetic gain x management interactions in soybean: I. Planting date. Crop Sci. 53, 1128-1138. doi: 10.2135/cropsci2012.03.0157

Rowntree, S. C., Suhre, J. J., Weidenbenner, N. H., Wilson, E. W., Davis, V. M., Naeve, S. L., et al. (2014). Physiological and phenological responses of historical soybean cultivar releases to earlier planting. Crop Sci. 54, 804-816. doi: 10.2135/ cropsci2013.06.0428

Salmeron, M., Gbur, E. E., Bourland, F. M., Buehring, N. W., Earnest, L., Fritschi, F., et al. (2016). Yield response to planting date amount soybean maturity groups for irrigated production in the US Midsouth. Crop Sci. 56, 747-759. doi: 10. 2135/cropsci2015.07.0466

Salmeron, M. H., Gbur, E. E., Bourland, F. M., Buehring, N. W., Earnest, L., Fritschi, F. B., et al. (2014). Soybean maturity group choices for early and late plantings in the US Midsouth. Agron. J. 106, 1893-1901. doi: 10.2134/agronj14. 0222

SAS Institute (2012). SAS Software Release 9.2. Cary, NC: SAS Institute.

Singer, J. W., Logsdon, S. D., and Meek, D. W. (2008). Soybean growth and seed yield response to tillage and compost. Agron. J. 100, 1039-1046. doi: 10.2134/ agronj2007.0360

TeKrony, D. M., Egli, D. B., Balles, J., Tomes, L., and Stuckey, R. E. (1984). Effect of date of harvest maturity on soybean seed quality and phomopsis sp. Seed information1. Crop Sci. 24, 189-193. doi: 10.2135/cropsci1984. 0011183X002400010045x

Wilson, E. W., Rowntree, S. C., Suhre, J. J., Weidenbenner, N. H., Conley, S. P., Davis, V. M., et al. (2014). Genetic gain $\times$ management interactions in soybean: II. Nitrogen utilization. Crop Sci. 54, 340-348. doi: 10.2135/cropsci2013.05.0339 Wood, C. W., Torbert, H. A., and Weaver, D. B. (1993). Nitrogen fertilizer effects on soybean growth, yield, and seed composition. J. Prod. Agric. 6, 354-360. doi: $10.2134 /$ jpa1993.0354

Conflict of Interest Statement: The authors declare that the research was conducted in the absence of any commercial or financial relationships that could be construed as a potential conflict of interest.

Copyright $\odot 2019$ Assefa, Purcell, Salmeron, Naeve, Casteel, Kovács, Archontoulis, Licht, Below, Kandel, Lindsey, Gaska, Conley, Shapiro, Orlowski, Golden, Kaur, Singh, Thelen, Laurenz, Davidson and Ciampitti. This is an open-access article distributed under the terms of the Creative Commons Attribution License (CC BY). The use, distribution or reproduction in other forums is permitted, provided the original author(s) and the copyright owner(s) are credited and that the original publication in this journal is cited, in accordance with accepted academic practice. No use, distribution or reproduction is permitted which does not comply with these terms. 